Katarzyna Zwolińska ${ }^{1}$

http://dx.doi.org/10.18778/8088-306.2.11

\title{
Zwolnienie z obowiązku świadczenia pracy odwołanego członka zarządu spółki handlowej
}

\section{Obowiązek pracodawcy rzeczywistego zatrudniania pracownika}

Zgodnie z treścią art. $22 \S 1$ Kodeksu pracy przez nawiązanie stosunku pracy pracownik zobowiązuje się do wykonywania pracy określonego rodzaju na rzecz pracodawcy i pod jego kierownictwem oraz w miejscu i czasie wyznaczonym przez pracodawcę, a pracodawca do zatrudniania pracownika za wynagrodzeniem. Sformułowany w ten sposób przepis określa elementy konstytutywne stosunku prawnego, przy których wypełnieniu przybiera on postać stosunku pracy. Po stronie pracodawcy możemy wyróżnić dwa obowiązki względem pracownika, rozłącznie wskazane przez ustawodawcę w art. 22 k.p., tj. zatrudnianie go przy pracy umówionej oraz wypłatę wynagrodzenia należnego za pracę.

Kwestią mającą istotne znaczenie dla dalszych rozważań dotyczących zagadnienia obowiązku zatrudniania pracownika przez pracodawcę będzie ustalenie rozumienia pojęcia wykonywania pracy jako powinności pracowniczej odpowiadającej omawianemu obowiązkowi pracodawcy 2 . W dawnej doktrynie prawa pracy wykształciły się na ten temat różne stanowiska, które podzieliły jej przedstawicieli na trzy obozy. Pierwsze z nich zakłada, iż świadczenie pracy oznacza gotowość do pracy lub aktywną obecność pracownika w zakładzie pracy33. Przedstawicielem tej teorii jest M. Święcicki, który wskazuje, iż pracownik dopełnia swojego obowiązku świadczenia pracy, gdy stawia do dyspozycji podmiotu zatrudniającego swą siłę roboczą, aby w konsekwencji pod jego kierownictwem ją aktywizować4. Również W. Piotrowski pisze, że pracownik wykonuje swoje zobowiązanie już poprzez samo zgłoszenie się w określonych odstępach czasu i umówionym miejscu do dyspozycji zatrudniającego, który przydziela mu narzędzia, surowce

\footnotetext{
1 Doktorantka, Uniwersytet Łódzki, Wydział Prawa i Administracji, Katedra Prawa Pracy.

2 A. Kijowski, Pracowniczy obowiq̨zek gotowości do świadczenia pracy, Poznań 1978, s. 13-16.

3 Przedstawicielami tego poglądu byli m.in. R. Korolec, Przerwy w świadczeniu pracy, PiP nr 7-8/1966, s. 119-120, czy M. Rafacz-Krzyżanowska, Odpowiedzialność majątkowa pracownika wobec zakładu pracy, Warszawa 1969, s. 60.

${ }^{4}$ M. Święcicki, Prawo pracy, 1968 r., s. 201-202.
} 
i kieruje procesem pracy ${ }^{5}$. W tym ujęciu to na pracodawcy spoczywa decyzja, w jaki sposób wykorzysta on postawioną do jego dyspozycji gotowość do pracy, a więc również, w jaki sposób będzie on realizował swój obowiązek zatrudniania.

Zgodnie z drugą koncepcją, świadczenie pracy polega na rzeczywistym wykonywaniu pracy albo na pozostawaniu w gotowości do jej wykonywania ${ }^{6}$. Nacisk został położony na rzeczywiste świadczenie pracy, przeciwstawiając mu prawne znaczenie tego pojęcia, niekoniecznie znajdujące pokrycie w fizycznym wykonywaniu określonych czynności przez pracownika. Zwolennicy trzeciego stanowiska przyjmują natomiast wąskie rozumienie pojęcia świadczenia pracy, tj. jako synonim jej rzeczywistego wykonywania ${ }^{7}$. Oczywiście nie wyklucza to wyjątkowych sytuacji, kiedy przerwa w wykonywaniu zadań pracowniczych nie pozbawia pracownika prawa do świadczeń od pracodawcy ${ }^{8}$, jednak nie można mówić wówczas o wykonywaniu pracy w ścisłym tego słowa znaczeniu. M. Seweryński pisze, iż uzasadnienia dla wąskiego rozumienia świadczenia pracy opartego wyłącznie na rzeczywistym wykonywaniu pracy przez pracownika należy upatrywać $\mathrm{w}$ interesie ekonomicznym pracodawcy - zatrudnia on w celu uzyskania korzyści, a tylko taka aktywność pracownika może je przynieść 9 . Wydaje się, iż spośród opisanych wyżej trzech odmiennych stanowisk, to ostatnie przyjmowane jest w obecnej doktrynie i orzecznictwie, jako punkt wyjścia do rozważań o obowiązku pracodawcy zatrudniania pracownika.

Obowiązek zatrudniania pracownika oznacza, że pracodawca jest obowiązany do umożliwienia mu rzeczywistego wykonywania pracy. Chodzi oczywiście o pracę, której rodzaj został określony w umowie o pracę łączącej obie strony. Ogólnie ujęty obowiązek zatrudniania pracownika został skonkretyzowany przez ustawodawcę w treści przepisu art. 94 k.p., stanowiącego o obowiązkach pracodawcy względem pracownika. Świadczenie przez pracownika pracy, do której

\footnotetext{
${ }^{5}$ W. Piotrowski, Roszczenia pracownika z tytułu bezprawnego pozbawienia miejsca pracy, Warszawa 1966, s. 48 i n.

${ }^{6}$ Za tą koncepcją opowiadał się m.in. J. Wratny, Wynagrodzenie akordowe a udział pracownika w ryzyku produkcyjnym, PiP 1973, nr 7, s. 106, czy A. Józefowicz, Charakterystyka gotowości do pracy, NP nr 7-8/1970, s. 1149-1150.

${ }^{7}$ A. Kijowski, Pracowniczy obowiązek gotowości do świadczenia pracy, Poznań 1978, s. 16.

8 Z. Salwa, Prawo pracy w zarysie, Warszawa 1971, s. 217.

${ }_{9}$ M. Seweryński, Wynagrodzenie za pracę. Pojęcie, regulacja i ustalenie, Łódź 1976, s. 75.
} 
się zobowiązał nie jest możliwe bez należytego współdziałania pracodawcy. Jak wskazuje J. Skoczyński oraz B. Wagner, ogólnie sformułowany obowiązek zatrudniania pracownika pracodawca realizuje m.in. przez zaznajamianie pracowników podejmujących pracę z zakresem ich obowiązków, sposobem wykonywania pracy na wyznaczonych stanowiskach oraz ich podstawowymi uprawnieniami, organizację pracy w sposób zapewniający pełne wykorzystanie czasu pracy, jak również osiąganie przez pracowników, przy wykorzystaniu ich uzdolnień i kwalifikacji, wysokiej wydajności i należytej jakości pracy, zapewnianie bezpiecznych i higienicznych warunków pracy oraz prowadzenie systematycznych szkoleń pracowników w zakresie bezpieczeństwa i higieny pracy ${ }^{10}$.

Omawianemu obowiązkowi pracodawcy odpowiada prawo pracownika do pracy, a co za tym idzie, roszczenie o dopuszczenie do pracy na podstawie art. $22 \S 1$ k.p. w związku z art. 471 k.c. ${ }^{11}$ Jeśli pracodawca działa wbrew swojemu zobowiązaniu, tj. dostarczaniu pracownikowi pracy zgodnie $\mathrm{z}$ umową, to $\mathrm{w}$ tym znaczeniu jego zachowanie jest bezprawne ${ }^{12}$. Co więcej, bezzasadne uniemożliwienie przez pracodawcę faktycznego wykonywania pracy przez pracownika może zostać zakwalifikowane na gruncie prawa pracy jako ciężkie naruszenie obowiązku współdziałania pracodawcy z pracownikiem przy wykonywaniu zobowiązania i stanowić może podstawę do rozwiązania stosunku pracy bez wypowiedzenia $\mathrm{z}$ winy pracodawcy (art. $55 \S 1^{1}$ k.p.) ${ }^{13}$.

Ponieważ dopuszczenie pracownika do pracy ma znaczenie konstytutywne dla uznania rzeczywistego istnienia stosunku pracy, wyjątki od konieczności jego wypełniania określać może tylko ustawa. W związku z tym pracodawca nie może według własnego uznania zrezygnować z obowiązku świadczenia pracy przez pracownika ${ }^{14} \mathrm{i}$ to nawet przy realizacji wobec niego obowiązku wypłaty wynagrodzenia.

\footnotetext{
10 J. Skoczyński, B. Wagner, Komentarz do art. 94 Kodeksu pracy, [w:] Kodeks pracy. Komentarz, red. L. Florek, LEX nr 104479.

11 Tak M. Raczkowski, Zwolnienie z obowiq̨zku świadczenia pracy a zasada realnego zatrudnienia, PiZS 2008, nr 3, s. 27.

12 Wyrok SN z dnia 16.06.2005 r., I PK 260/04, OSNP 2006, nr 9-10, poz. 145.

13 Wyrok SN z dnia 20.09.2013 r., II PK 6/13, OSNP 2014/6/81; tak też: J. Skoczyński,

B. Wagner, Komentarz do art. 94 Kodeksu pracy, [w:] Kodeks pracy. Komentarz, red.

L. Florek, LEX nr 104479.

14 Wyrok SN z dnia 28.10.1998 r., I PKN 361/98, OSN 1999/23/750
} 
Zwolnienie pracownika z obowiązku wykonywania pracy nie oznacza bowiem uchylenia jego prawa do pracy ${ }^{15}$.

Z powyższego wynika, iż ze względu na dwustronny charakter stosunku pracy oraz wzajemność świadczeń stron tego stosunku, uchylenie się pracodawcy od obowiązku zatrudniania pracownika przez zwolnienie go od obowiązku świadczenia pracy jest co do zasady niedozwolone, a z ekonomicznego punktu widzenia również nieuzasadnione. Realizacja stosunku pracy w praktyce pokazuje jednak, iż świadczenie przez pracownika w postaci wykonywania umówionej pracy nie zawsze jest możliwe lub leży w interesie pracodawcy.

Ustawodawca sam wskazał okoliczności, w których świadczenie pracy przez pracownika mimo jego gotowości do pracy jest niemożliwe lub uprawnia pracodawcę do jednostronnego zwolnienia pracownika z obowiązku wykonywania pracy. Chodzi tu m.in. o sytuację, kiedy pracodawca, jeśli jest to uzasadnione jego potrzebami, może odstąpić od wypełniania obowiązku zapewnienia pracownikowi możliwości wykonywania umówionej pracy, powierzając mu wykonywanie innej pracy na warunkach określonych w art. $42 \S 4$ k.p. Kodeks pracy dopuszcza również jednostronne stałe lub okresowe odsunięcie pracownika od pracy lub przeniesienie do wykonywania innej pracy w sytuacjach ściśle określonych przez ustawę m.in. ze względu na stan zdrowia pracownika (np. art. $201 \S 2$, art. $42 \S 4$, art. $81 \S 3$, art. 179, art. 230 i 231 Kodeksu pracy). Regulacje te stanowią wyłom od obowiązku zatrudniania pracownika do pracy umówionej, wskazując przy tym określony sposób dopuszczalnego postępowania pracodawcy wobec pracownika.

Dodatkowo, przy omawianiu ustawowych wyjątków od obowiązku zatrudniania pracownika przez pracodawcę, istotne znaczenie ma przepis art. 81 k.p., który stanowi, że pracownikowi za czas niewykonywania pracy, jeżeli był gotów do jej wykonywania, a doznał przeszkód z przyczyn dotyczących pracodawcy, przysługuje wynagrodzenie wynikające $\mathrm{z}$ jego osobistego zaszeregowania, określonego stawką godzinową lub miesięczną, a jeżeli taki składnik wynagrodzenia nie został wyodrębniony przy określaniu warunków wynagradzania - $60 \%$ wynagrodzenia. Z hipotezy tego przepisu wynika wprost, iż ustawodawca przewidział okoliczności, w których pracownik nie wykonuje

15 P. Prusinowski, Zwolnienie z obowiq̨zku świadczenia pracy - czynność jednostronna czy porozumienie stron, MoPrPr 2012, nr 4, s. 174. 
pracy z przyczyn leżących po stronie pracodawcy, w ten sposób dopuszcza więc on sytuację, kiedy nie jest realizowany obowiązek pracodawcy do zatrudniania pracownika.

Brak regulacji prawnej dotyczącej wprost uprawnienia pracodawcy do zwolnienia pracownika z obowiązku świadczenia pracy nie okazał się jednak dostatecznym argumentem dla niestosowania go przez pracodawców w rzeczywistości.

\section{Zatrudnianie członka zarządu spółki prawa handlowego}

Powołanie do pełnienia funkcji członka zarządu spółki prawa handlowego następuje uchwałą zgromadzenia wspólników tej spółki i prowadzi do powstania stosunku organizacyjno prawnego między osobą sprawującą tę funkcję a spółką, którą zarządza. Z pełnieniem funkcji członka zarządu w spółce łączy się szereg obowiązków o charakterze kierowniczym, w rzeczywistości możemy więc mówić o świadczeniu pracy na rzecz spółki w postaci pełnienia zarządu. Jednak jak wskazuje Sąd Najwyższy, powołanie w skład zarządu spółki kapitałowej jest tylko aktem inwestytury na określoną funkcję, na mocy tego powołania nie powstaje stosunek pracy; aby między spółką a członkiem jej zarządu powstał stosunek pracy niezbędne jest zawarcie umowy o pracę ${ }^{16}$. W związku z tym, w praktyce najczęściej spółka zawiera $\mathrm{z}$ powołanym członkiem zarządu umowę o pracę, przede wszystkim dla zabezpieczenia jego interesów poprzez włączenie go do kręgu podmiotów podlegających ubezpieczeniu społecznemu. Stosunek pracy obejmuje wykonywanie obowiązków zarządczych na stanowisku członka zarządu spółki, stanowi więc swego rodzaju powielenie podstawy prawnej ich wykonywania. W orzecznictwie wskazuje się, iż w przypadku, gdy z członkiem zarządu nawiązuje się umowę o pracę i to w tym celu, by jego powinności jako członka zarządu były jednocześnie jego obowiązkami pracowniczymi (obowiązek pracy polega na wykonywaniu funkcji zarządu, do czego członek zarządu jest zobowiązany także równocześnie na podstawie przepisów prawa handlowego), dochodzi do powstania szczególnej sytuacji prawnej. Ze stosunkiem członkostwa w zarządzie spółki (stosunkiem prawnym z zakresu prawa handlowego) sprzężony zostaje stosunek pracy (umowa o pracę) ${ }^{17}$. Mamy więc do czynienia ze specyficzną sytuacją równoległego istnienia dwóch stosunków prawnych - pracy oraz organiza-

\footnotetext{
16 Wyrok SN z 2.12.2010 r., II PK 131/10; wyrok SN z 19.11.2013 r., I PK 120/13.

17 Wyrok SN z 26.01.2000 r., I PKN 479/99, OSNP 2001, nr 11, poz. 377.
} 
cyjno-prawnego, które mimo iż swoim zakresem przedmiotowym obejmują takie same obowiązki pracownika-członka zarządu, jednak zachowują swoją odrębność. Dopóki oba te stosunki prawne trwają i są wykonywane bez przeszkód, ta specyficzna sytuacja prawna nie rodzi trudności związanych z jej harmonijną realizacją. Problemy natury praktycznej pojawiają się jednak w przypadku, kiedy pracownik-członek zarządu zostaje pozbawiony możliwości wykonywania swojej pracy na tym stanowisku, i to nie tylko z przyczyn organizacyjnych, ale także prawnych. Odrębność stosunku organizacyjno-prawnego i stosunku pracy członka zarządu spółki prawa handlowego powoduje bowiem, że z odwołaniem pracownika z funkcji w zarządzie ustaje tylko stosunek organizacyjno-prawny, a stosunek pracy trwa do czasu, aż zostanie rozwiązany przez pracodawcę lub pracownika albo za ich porozumieniem ${ }^{18}$. Jeżeli członek zarządu zostaje odwołany ze swojej funkcji, to nie może on realizować praw i obowiązków członka zarządu nawet, jeśli wynikają one $\mathrm{z}$ umowy o pracę. W następstwie odwołania osoba ta powinna być odsunięta od podejmowania czynności, które dotychczas należały do jej kompetencji i to bez względu na istniejący lub nie stosunek zobowiązaniowy. Rozwiązanie jednego z równoległych stosunków prawnych, organizacyjno-prawnego, powoduje więc realną niemożność wykonywania stosunku pracy przez pracownika. Stąd też SN uznał, iż w takiej sytuacji odwołanie ze stanowiska członka zarządu spółki, które nie zostało skutecznie podważone w trybie przepisów prawa handlowego, z reguły stanowi przyczynę uzasadniającą wypowiedzenie umowy o pracę (art. $45 \S 1$ k.p.) pracownikowi zatrudnionemu w charakterze członka tego zarządu ${ }^{19}$. Istotne znaczenie odnośnie do problematyki odrębności dwóch omawianych stosunków prawnych będzie miała kwestia przywrócenia do pracy na stanowisko członka zarządu pracownika, wobec którego orzeczono nieuzasadnione rozwiązanie umowy o pracę. Sąd Najwyższy ze względu na praktyczne problemy związane z niemożnością dalszej realizacji stosunku pracy w przypadku skutecznego odwołania członka zarządu stał na stanowisku, iż to roszczenie pracownika nie ma w tej sytuacji zastosowania $^{20}$. Jednolita linia orzecznicza została jednak przełamana uchwałą SN z dnia 16.05.2012 r., w której to SN orzekł, iż w przypadku rozwiązania z naruszeniem prawa umowy o pracę z członkiem zarządu spółki kapitałowej odwołanym na podstawie art. $203 \S 1$ lub art. $370 \S 1$ ustawy

\footnotetext{
18 Wyrok SN z 19.06.2012 r., II UK 282/11.

19 Wyrok SN z 3.03.2011 r., II PK 201/10, LEX nr 1084554.

20 Wyrok SN z 17.08.2006 r., III PK 53/06, OSNP 2007/17-18/245.
} 
z dnia 15 września 2000 r. Kodeks spółek handlowych (Dz.U. Nr 94, poz. 1037 ze zm.) nie jest wyłączone roszczenie o przywrócenie do pracy. Prezentowane wcześniej przez Sąd Najwyższy stanowisko bardziej odpowiadało specyfice pracowniczego zatrudnienia członków zarządu spółek kapitałowych. Samo przywrócenie do pracy odwołanego członka zarządu nie przywraca mu bowiem umocowania do zarządzania spółką i jej reprezentowania, co zostało z resztą podkreślone również przez Sąd Apelacyjny w Białymstoku w wyroku z 5.11.2013, w którym orzekł, iż skoro pracodawca zdecydował się na równoczesne rozwiązanie stosunku pracy i stosunku korporacyjnego, to wadliwość jednego z nich nie oznacza wadliwości drugiego ${ }^{21}$. Dopuszczenie przez SN możliwości przywrócenia do pracy odwołanego członka zarządu spółki implikuje dalsze problemy nie tylko po stronie pracownika, związane z niemożnością świadczenia przez niego pracy, ale również po stronie pracodawcy, na którym spoczywa obowiązek rzeczywistego zatrudniania tego pracownika.

\section{Zwolnienie z obowiązku świadczenia pracy odwołanego członka zarządu}

Sąd Najwyższy w wyroku z dnia 16.06 .2005 r. orzekł o dopuszczalności odsunięcia pracownika od pracy na mocy jednostronnej decyzji pracodawcy w imię ochrony jego interesów, w sytuacji zwolnienia w okresie wypowiedzenia pracownika kadry zarządzającej (w tym członków zarządów spółek prawa handlowego) odwołanego z pełnionej funkcji w organie zarządzającym ${ }^{22}$. Jako podstawę odwołania i wiążącej się z nim niedopuszczalności dalszego wykonywania funkcji wskazuje się w tym przypadku ustawę (art. 203, art. 370 k.s.h.). W związku z częstym brakiem możliwości zakończenia w tym samym czasie obu stosunków prawnych i dalszym trwaniem stosunku pracy, dochodzi do sytuacji, w której wykonywanie obowiązków przez pracownika odwołanego z pełnionej przez niego funkcji zarządczej nie ma racji bytu, wręcz przeciwnie może prowadzić do niedogodności po obu stronach. Pracownik nie może w pełnym zakresie wykonywać swoich obowiązków, gdyż nie posiada do tego uprawnień w ramach funkcji, do której powinien zostać powołany, pracodawca natomiast mimo ciążącego na nim obowiązku dalszego zatrudniania pracownika nie może dopuścić go do dotychczasowych czynności wykonywanych w ramach stosunku pracy, a uzależnionych od pełnienia funkcji zarządczej.

21 Wyrok SA w Białymstoku z 5.11.2013 r., III APa 18/13.

22 Wyrok SN z dnia 16.06.2005 r., I PK 260/04, OSNP 2006, nr 9-10, poz. 145. 
W konsekwencji należy sięgnąć do alternatywnych środków „ochrony” pracodawcy przed niechcianym, a mogącym wyrządzić szkodę pracownikiem, a zwolnienie pracownika z obowiązku świadczenia pracy (do czasu zakończenia stosunku pracy) $\mathrm{w}$ tych konkretnych okolicznościach wydaje się być racjonalnym rozwiązaniem ${ }^{23}$.

Uznając specyfikę sytuacji związanej z odwołaniem członka zarządu spółki pozostającego nadal w zatrudnieniu pracowniczym w pełni należy podzielić pogląd Sądu Najwyższego co do dopuszczalności zwolnienia z obowiązku wykonywania pracy. Problematyczną pozostaje jednak nadal kwestia zastosowania tego instrumentu wobec innych pracowników zwłaszcza w okresie wypowiedzenia, których praca nie jest bezpośrednio powiązana z pełnieniem określonej funkcji, lecz w danych okolicznościach odsunięcie ich od wykonywania pracowniczych obowiązków leży w interesie pracodawcy, choćby ze względu na utratę zaufania. W projekcie najnowszej nowelizacji Kodeksu pracy instytucja zwolnienia z obowiązku świadczenia pracy jest wprost uregulowana w przepisach, co stanowi wyraz dostrzeżenia potrzeby sięgania do takich rozwiązań przez pracodawców, którzy w imię ochrony własnych interesów lub $w$ ramach realizacji swojego kierownictwa w zakresie organizacji pracy, rezygnują ze świadczenia pracy na swoją rzecz.

\section{Wynagrodzenie dla odwołanego członka zarządu zwolnionego z obowiązku wykonywania pracy}

W konsekwencji braku regulacji prawnej dotyczącej uprawnienia pracodawcy do zwolnienia pracownika z obowiązku świadczenia pracy, również kwestia wynagrodzenia w sytuacji odsunięcia go od obowiązków pracowniczych nie została uregulowana.

W wyroku z dnia 16.06.2005 r., orzekł, że pracownik zwolniony przez pracodawcę z obowiązku świadczenia pracy doznaje przeszkód $\mathrm{w}$ jej wykonywaniu z przyczyn dotyczących pracodawcy (art. $81 \S 1$ k.p.) i z tego tytułu przysługuje mu wynagrodzenie w wysokości określonej $\mathrm{w}$ tym przepisie ${ }^{24}$. Z drugiej strony z powodu braku regulacji prawnej w praktyce pracodawcy, nie chcąc wchodzić w konflikt z pracownikami, których odsunięto od pracy w okresie wypowiedzenia, wypłacają im za czas nieświadczenia pracy wynagrodzenie jak za urlop

23 J. Czerniak-Swędzioł, S. Koczur, Granice możliwości zwolnienia pracownika z obowiq̨zku świadczenia pracy, [w:] Studia z zakresu prawa pracy i polityki społecznej, red. A. Świątkowski, rocznik 2013, s. 276.

24 Wyrok SN z dnia 16.06.2005 r., I PK 260/04, OSNP 2006, nr 9-10, poz. 145. 
wypoczynkowy lub ekwiwalent za urlop wypoczynkowy, czyli wynagrodzenie ustalone na podstawie rozporządzenia Ministra Pracy i Polityki Socjalnej z 8 stycznia 1997 r. w sprawie szczególnych zasad udzielania urlopu wypoczynkowego, ustalania i wypłacania wynagrodzenia za czas urlopu oraz ekwiwalentu pieniężnego za urlop25, do którego odsyła inne rozporządzenie poświęcone sposobom ustalania wynagrodzenia w okresie niewykonywania pracy, a mianowicie rozporządzenie Ministra Pracy i Polityki Socjalnej z 29 maja 1996 r. w sprawie sposobu ustalania wynagrodzenia w okresie niewykonywania pracy oraz wynagrodzenia stanowiącego podstawę obliczania odszkodowań, odpraw, dodatków wyrównawczych do wynagrodzenia oraz innych należności przewidzianych w Kodeksie pracy ${ }^{26}$. Ten sposób obliczania wynagrodzenia należnego pracownikowi zwolnionemu z obowiązku wykonywania pracy popiera P. Prusinowski ${ }^{27}$, który wskazuje, iż zwolnienie z obowiązku pracy znaczy jedynie tyle, że pracownik nie jest obowiązany wykonywać czynności wynikających z umowy, nie zostaje on jednak zwolniony ze wszystkich obowiązków; nadal posiada status pracownika i spoczywają na nim z tego tytułu powinności, takie jak dbałość o dobro zakładu pracy, zachowanie w tajemnicy informacji ważnych dla zatrudniającego, przestrzeganie zakazu konkurencji ${ }^{28}$. W tej sytuacji pracownik powinien otrzymać wynagrodzenie w wysokości takiej, jak gdyby normalnie pracował. Zastosowanie art. $81 \S 1$ k.p. zostaje wykluczone $\mathrm{z}$ uwagi na warunek zachowania przez pracownika gotowości do pracy, który nie jest wymagany w przypadku zwolnienia go z obowiązku świadczenia pracy ${ }^{29}$. Stosowanie powołanych wyżej przepisów do pracownika zwolnionego z obowiązku świadczenia pracy jest niewątpliwie korzystniejsze dla pracownika niż przepisów o wynagrodzeniu za czas niewykonywania pracy z przyczyn dotyczących pracodawcy, których to możliwość zastosowania rozważał SN. Ostatecznie

\footnotetext{
25 Rozporządzenie Ministra Pracy i Polityki Socjalnej z 8 stycznia 1997 r. w sprawie szczególnych zasad udzielania urlopu wypoczynkowego, ustalania i wypłacania wynagrodzenia za czas urlopu oraz ekwiwalentu pieniężnego za urlop, Dz.U., Nr 2, poz. 14 ze $\mathrm{zm}$.

26 Rozporządzenie Ministra Pracy i Polityki Socjalnej z 29 maja 1996 r. w sprawie sposobu ustalania wynagrodzenia w okresie niewykonywania pracy oraz wynagrodzenia stanowiącego podstawę obliczania odszkodowań, odpraw, dodatków wyrównawczych do wynagrodzenia oraz innych należności przewidzianych w Kodeksie pracy, Dz.U. Nr 62, poz. 289.

27 P. Prusinowski, Zwolnienie z obowiq̨zku..., s. 175.

28 T. Liszcz, Glosa do wyroku SN z dnia 5.07.2005 r., I PK 176/04, OSP nr 1/2007, poz. 4.

${ }^{29}$ P. Prusinowski, Zwolnienie z obowiq̨zku..., s. 176,
} 
przyjął jednak, iż pracownikowi zwolnionemu z obowiązku świadczenia pracy z przyczyn leżących po stronie pracodawcy należy się tylko wynagrodzenie $\mathrm{w}$ wysokości wynikającej $\mathrm{z}$ art. $81 \S 1$ k.p., zgodnie z którym pracownikowi za czas niewykonywania pracy, jeżeli był gotów do jej wykonywania, a doznał przeszkód z przyczyn dotyczących pracodawcy, przysługuje wynagrodzenie wynikające $\mathrm{z}$ jego osobistego zaszeregowania, określonego stawką godzinową lub miesięczną, a jeżeli taki składnik wynagrodzenia nie został wyodrębniony przy określaniu warunków wynagradzania - 60\% wynagrodzenia ${ }^{30}$. Możliwość zastosowania w takim przypadku art. $81 \S 1$ k.p. uzasadniono tym, iż pracownik odsunięty od wykonywania pracy (zwolniony z obowiązku świadczenia pracy) doznaje przeszkód w jej wykonywaniu z przyczyn dotyczących pracodawcy, który podejmuje decyzję o takim odsunięciu (zwolnieniu). Pojęcie przyczyn uzasadniających powstanie prawa do wynagrodzenia gwarancyjnego określonego w art. 81 § 1 k.p., należnego w sytuacjach niewykonywania pracy, zostało więc zinterpretowane w sposób szeroki, zakładając, iż mieści się wśród nich także sytuacja odsunięcia pracownika od wykonywania obowiązków lub zwolnienie go z obowiązku świadczenia pracy31.

Moim zdaniem, z uwagi na specyfikę opisywanej instytucji i brak jej regulacji prawnej, pracownik powinien zachować prawo do pełnego wynagrodzenia. $\mathrm{W}$ przeciwnym razie stosowanie zwolnienia od wykonywania pracy mogłoby zostać wykorzystywane przez pracodawców pośrednio dla obniżenia wynagrodzenia pracownika, zwłaszcza przy przyjęciu tak szerokiego ujęcia przesłanki jego zastosowania jak przyczyny leżące po stronie pracodawcy.

\section{Podsumowanie}

Podsumowując powyższe rozważania należy stwierdzić, iż specyfika sytuacji prawnej członka zarządu spółki prawa handlowego pozostającego równolegle $\mathrm{w}$ zatrudnieniu pracowniczym na stanowisku członka zarządu, stanowi argument za dopuszczeniem szczególnych rozwiązań prawnych wobec niego w sytuacji odwołania z pełnionej w spółce funkcji i tym samym niemożności wykonywania pracy ze stosunku pracowniczego - nawet mimo braku ku temu podstaw prawnych $\mathrm{w}$ prawie pracy. Zwolnienie z obowiązku wykonywania pracy do czasu

\footnotetext{
30 Zob. też wyrok Sądu Najwyższego z dnia 16.11.2000 r., I PKN 455/00, OSNAPiUS 2002, nr 11, poz. 268.

31 Uzasadnienie do wyroku SN z dnia 16.06.2005 r., I PK 260/04, OSNP 2006, nr 9-10, poz. 145.
} 
rozwiązania stosunku pracy stanowi instrument najbardziej efektywny, jaki zastosować może w takim przypadku pracodawca. Zachowanie przez zwolnionego pracownika prawa do wynagrodzenia w pełnej wysokości wydaje się stanowić dostateczne zabezpieczenie interesów pracownika i pełnić rolę gwarancyjną w sytuacji dopuszczającej w drodze wyjątku zaniechanie pracodawcy wypełniania wobec tego pracownika z podstawowego obowiązku rzeczywistego zatrudniania. 